\title{
Natural Occurrence of Beauveria bassiana (Balsamo) Vuillemin (Hypocreales: Clavicipitaceae) on Anticarsia gemmatalis Hübner (Lepidoptera: Erebidae) in the State of Mato Grosso do Sul
}

\author{
Camila Rossoni, Samir Oliveira Kassab ${ }^{\bowtie}$, Rogério Hidalgo Barbosa, Antonio Souza Silva, \\ Thiago Alexandre Mota \& Elisângela de Souza Loureiro
}

Universidade Federal da Grande Dourados, e-mail: camilasrossoni@gmail.com, samirkassab@gmail.com (Autor para correspondência ${ }^{\bowtie}$ ), hidalgo.rogerio@gmail.com, antoniobios@yahoo.com.br, thiamota@hotmail.com, elisangela.loureiro@ufms.br.

\section{EntomoBrasilis 6(2): 162-164 (2013)}

Abstract. Natural occurrence of an entomopathogenic fungus was reported on Anticarsia gemmatalis Hübner (Lepidoptera: Erebidae) in an area planted with conventional soybeans located in Dourados, Mato Grosso do Sul, Brazil. The caterpillar was collected in the field and taken to the microbiology laboratory of the Universidade Federal da Grande Dourados (UFGD) where it remained in a moist chamber for approximately 7 days. Later, the fungus was isolated on culture medium (PDA) for identification of the entomopathogenic species. The fungus was identified as Beauveria bassiana (Balsamo) Vuillemin (Hypocreales: Clavicipitaceae) and this represents the first record of parasitism of this species on the soybean caterpillar in the state of Mato Grosso do Sul.

Keywords: Biological control; Entomopathogens; Soybean caterpillar.

\section{Ocorrência Natural de Beauveria bassiana (Balsamo) Vuillemin (Hypocreales: Clavicipitaceae) Sobre Anticarsia gemmatalis Hübner (Lepidoptera: Erebidae) no Estado de Mato Grosso do Sul}

Resumo. Relata-se a ocorrência natural de um fungo entomopatogênico sobre a lagarta Anticarsia gemmatalis Hübner (Lepidoptera: Erebidae) em uma área de soja convencional situada no município de Dourados, Mato Grosso do Sul. A lagarta foi coletada a campo e levada ao laboratório de microbiologia da Universidade Federal da Grande Dourados (UFGD), onde permaneceu em câmera úmida por aproximadamente 7 dias. Posteriormente, o fungo foi isolado em meio de cultura (BDA) para identificação da espécie do entomopatógeno. O fungo foi identificado como Beauveria bassiana (Balsamo) Vuillemin (Hypocreales: Clavicipitaceae) e, isso representa o primeiro registro de parasitismo, dessa espécie, sobre a lagarta-da-soja no Estado de Mato Grosso do Sul.

Palavras-chave: Controle biológico; Entomopatógenos; Lagarta-da-soja.

$\sqrt{\Omega}$ The soybean caterpillar, Anticarsia gemmatalis Hübner (Lepidoptera: Erebidae) is a major defoliating insect pest of brazilian soybean in Brazil, encountered found in all locations where this crop is cultivated produced (FreITAS BuEno et al. 2011; WIEST \& BARRETO 2012). Attack of A. gemmatalis compromises the quality of Brazilian soybean crops and defoliation may affect filling of the grains and pods of the plant, resulting in reduced yields (Levy et al. 2011).

The control of A. gemmatalis is generally usually performed by application spraying of chemical insecticides BERNARDIetal.(2012). The viruses (Baculovirus anticarsia) and entomopathogenic fungi are responsible for biological control of pest populations of A. gemmatalis (Piubelli et al. 2006; SosA-Gómez et al. 2010).

Entomopathogenic fungi are responsible for approximately $80 \%$ of diseases caused in insects and are important regulators of insect pest populations (LoureIro et al. 2005). These control agents present advantages over other entomopathogens, including: infection of the different developmental stages of the host, penetration via integument and high capacity for spreading throughout the crop (ALVES 1998).

In Brazil, the natural occurrence of entomopathogens on Lepidoptera has been reported since the 1970's. Among the soybean defoliating caterpillar species recorded for parasitism by entomopathogenic fungi are: A. gemmatalis along with occurrence of Nomuraea rileyi (Farlow) Samson (Hypocreales: Clavicipitaceae), Pseudoplusia includens Walker (Lepidoptera: Noctuidae) and Trichoplusia ni Hübner (Lepidoptera: Noctuidae) with natural infection of the fungi Zoophthora radicans Brefeld (Humber) (Entomophthorales: Entomophthoraceae) and Paecilomyces tenuipesu (Peck) Samson (Hypocreales: Clavicipitaceae), respectively (SOSA-Gómes 2002). In other studies, the occurrence of the fungi Paecilomyces amoenoroseus (Hennings) Samson (Hypocreales: Clavicipitaceae) Neozygites sp.,Aschersonia aleyrodis Webber (Hypocreales: Clavicipitaceae) has been recorded in Lagria villosa (Fabricius) (Coleoptera: Tenebrionidae), Tetranychusurticae Koch (Acari:Tetranychidae) and whitefly, respectively (SOSA-Gómes et al. 2001).

The entomopathogenic fungus Beauveria bassiana (Balsamo) Vuillemin (Hypocreales: Clavicipitaceae) acts as a natural control agent for Aracanthus mourei Rosado Neto (Coleoptera: Curculionidae) and Diabrotica speciosa Germar (Coleoptera: Chrysomelidae) (Ownley et al. 2008). However, natural occurrence of B. bassiana on A. gemmatalis has not yet been registered in the state of Mato Grosso do Sul. Therefore, the objective of the present study was to report natural occurrence of B. bassiana on A. gemmatalis in, where this is the first record for the Brazilian state of Mato Grosso do Sul. 
T In February 2012 natural occurrence of entomopathogenic fungi on the caterpillar A. gemmatalis was observed in conventional soybeans (cv. EMBRAPA 48), in a test plot located in the UFGD experimental farm in the municipality of Dourados, MS, Brazil, whose latitude is $22^{\circ} 11^{\prime} 53$ " S, longitude $54^{\circ} 55^{\prime} 59^{\prime \prime} \mathrm{W}$, and altitude $430 \mathrm{~m}$. The area that was recorded the insect presence had 1 ha., the spacing between plants cultivated was $0.45 \mathrm{~m}$. The plants growth stage was $\mathrm{R}_{3}$ in a conventional cultive system.

The caterpillar collected (Figure $01 \mathrm{~A}$ and $\mathrm{B}$ ) was sent to the Laboratory of Microbiology, Faculdade de Ciências Biológicas e Ambientais (FCBA) of the Universidade Federal da Grande Dourados (UFGD) in Dourados, Mato Grosso do Sul, Brazil. It was immersed in $70 \%$ alcohol and distilled water for superficial disinfection of the insect and then transferred to a Petri dish containing a piece of sterilized and moistened cotton. The plate was kept in a BOD at temperature of $26 \pm 2{ }^{\circ} \mathrm{C}$ and $14 \mathrm{~h}$ photophase to promote sporulation (ALVES 1998).

Samples of the parasitized caterpillar were taken and subjected to the isolation procedure described by Alves (1998). The Petri dishes containing culture medium were inoculated and incubated for 10 days ( $26 \pm 1{ }^{\circ} \mathrm{C}$ and $14 \mathrm{~h}$ photoperiod). Afterwards this, samples of the colonies were observed under an optical microscope and the presence of conidia was observed; fungi were then inoculated on PDA culture medium (200 g potatoes, $20 \mathrm{~g}$ dextrose, $15 \mathrm{~g}$ agar and $1000 \mathrm{~mL}$ of distilled water). The inoculated petri dishes were incubated for 10 days $\left(26 \pm 2{ }^{\circ} \mathrm{C}\right.$ e $14 \mathrm{~h}$ photoperiod).

From the morphological characteristics described by HuMBER (1998), the fungus was identified as B. bassiana (Figure 1C). The mycelium encountered on the cadaver was white and phialides presented a globose base, extending apically in a zigzag direction (rachis). Conidia are globose and grouped in conidiophores (Figure 1D). The fungus B. bassiana is well-known in Brazil for its ability to parasitize and cause the death of many insect species of agricultural importance. In Brazil there are no reports of natural occurrence $B$. bassiana in A. gemmatalis and this is the first record that was observed in the State of Mato Grosso do Sul.

The results of this study can indicate a viable alternative for the management of $A$. gemmatalis. However, it is emphasized that studies are needed on efficiency of the entomopathogen $B$. bassiana to control the soybean caterpillar so that the fungus can be used to control this pest. It is important that compatibility studies for fungicides used in soybeans with the entomopathogenic fungus are performed to show if pesticides interfered on growth and development of the natural enemy of $B$. bassiana.
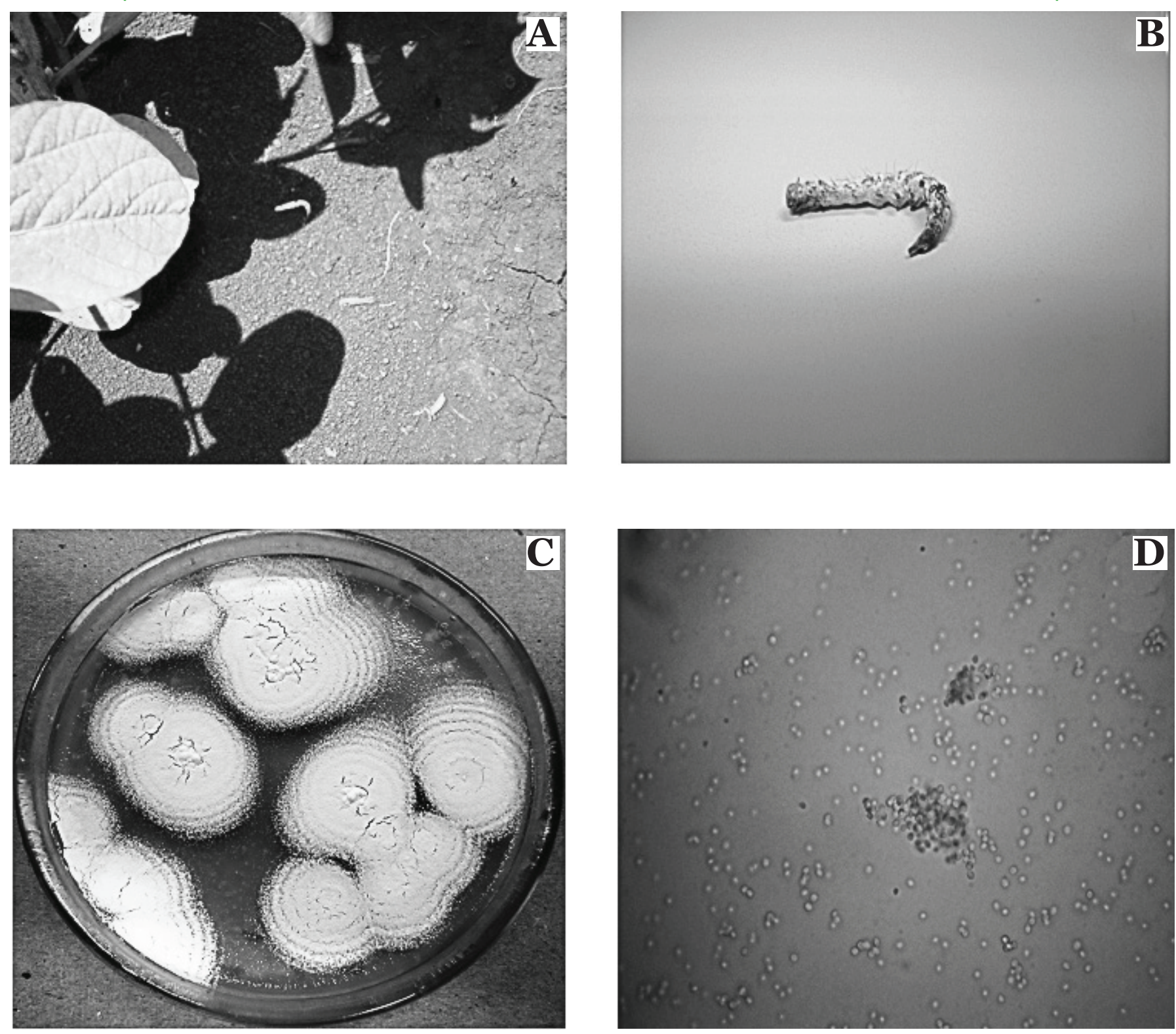

Figure 1. Caterpillar of Anticarsia gemmatalis (Lepidoptera: Erebidae) in the field (A) and laboratory (B); colonies of the fungus Beauveria bassiana (Hypocreales: Clavicipitaceae) in PDA culture medium (C); conidia and conidiophores of $B$. bassiana observed by optical microscopy (40oX) (D). Author: Kassab, S.O. 


\section{REFERENCES}

Alves, S.B,1998. Controle microbiano de insetos. Piracicaba, FEALQ, 1163p.

Bernardi, O., G.S. Malvestiti, P.M. Dourado, W.S. Oliveira, S. Martinelli, G.U. Berger, G.P. Head \& C. Omoto, 2012. Assessment of the high-dose concept and level of control provided by MON $87701 \times$ MON 89788 soybean against Anticarsia gemmatalis and Pseudoplusia includens (Lepidoptera: Noctuidae) in Brazil. Pest Management Science, 68: 1083-1091.

Freitas Bueno, R.C.O., J.R.P. Parra \& A. de Freitas Bueno, 2011. Trichogramma pretiosum parasitism and dispersal capacity: a basis for developing biological control programs for soybean caterpillars. Bulletin of Entomological Research, 102: 1- 8.

Humber, R.A., 1998. Entomopathogenic fungal identification. Available in: <http://www.ars.usda.gov/SP2UserFiles/ Place/19070510/APSwkshoprev.pdf >. Acessed: 22 June 2012.

Levy, S.M., A.M.F. Falleiros, F. Moscardi \& E.A. Gregório, 2011. The role of peritrophic membrane in the resistance of Anticarsia gemmatalis larvae (Lepidoptera: Noctuidae) during the infection by its nucleopolyhedrovirus (AgMNPV). Arthropod Structure \& Development, 40: 429-434.

Loureiro, E.S., A. Batista Filho, J.E.M. Almeida \& L.G.A. Pessoa, 2005. Seleção de isolados de Metarhizium anisopliae (Metch.) Sorok. contra a cigarrinha da raiz da cana-de-açúcar Mahanarva fimbriolata (Stal) (Hemiptera: Cercopidae) em laboratório. Neotropical Entomology, 34: 791-798.
Ownley, B.H., M.R. Griffin, W.E. Klingeman, K.D. Gwinn, J.K. Moulton \& R.M. Pereira, 2008. Beauveria bassiana: endophytic colonization and plant disease control. Journal of Invertebrate Pathology, 98: 267-70.

Piubelli, G.C., C.B Hoffmann-Campo, F. Moscardi, S.H. Miyakubo \& M.C.N. Oliveira. 2006. Baculovirus resistant Anticarsia gemmatalis respond differently to dietary rutin. Entomologia Experimentalis et Applicata, 119: 53-60.

Sosa-Gómez,D.R.\&J.J.daSilva,2002.Fungosentomopatogênicos: catálogos de isolados. Londrina: EMBRAPA (Boletim de Pesquisa e Desenvolvimento, 188), 32 p.

Sosa-Gómez, D.R., C.C. López Lastra \& R.A. Humber, 2010. An Overview of arthropod-associated fungi from Argentina and Brazil. Mycopathologia, 170: 61-76.

Sosa-Gómez, D.R., E.D. Katiaíres, F. Moscardi \& J.R.B. Farias, 2001. Natural Occurrence of the Entomopathogenic Fungi Metarhizium, Beauveria and Paecilomyces in Soybean Under Till and No-till Cultivation Systems. Neotropical Entomology, 30: 407-410.

Wiest, A. \& M. R. Barreto, 2012. Evolução dos Insetos-Praga na Cultura da Soja no Mato Grosso. 2012. Entomobrasilis, 5: 8487 .

Recebido em: 05/o7/2012

Aceito em: 24/01/2013

\section{Como citar este artigo:}

Rossoni, C., S.O. Kassab, R.H. Barbosa, A.S. Silva, T.A. Mota \& E.S. Loureiro, 2013. Natural Occurrence of Beauveria bassiana (Balsamo) Vuillemin (Hypocreales: Clavicipitaceae) on Anticarsia gemmatalis Hübner (Lepidoptera: Erebidae) in the State of Mato Grosso do Sul. EntomoBrasilis, 6(2): 162-164.

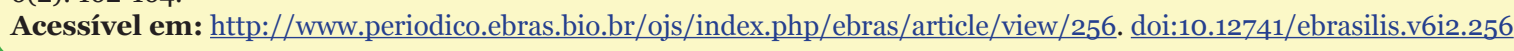

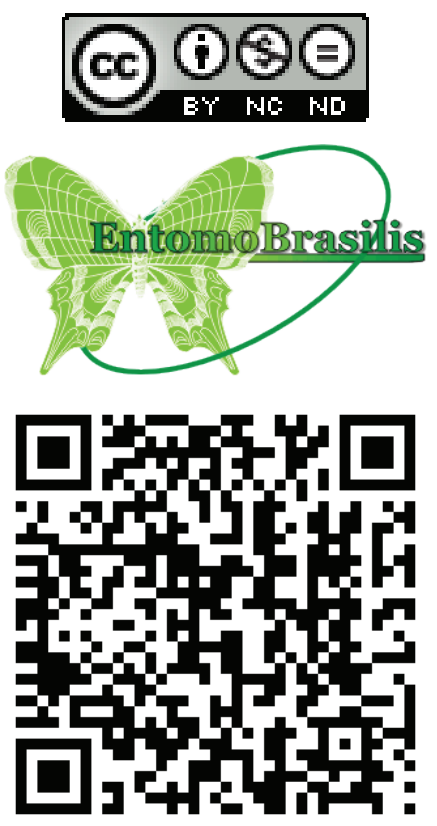

